\title{
特別養護老人ホームにおけるユニット調理の効果と課題 ーリビングルームの観察と調理職員の行動観察調査を通してー \\ EFFECTS AND ISSUES OF “COOKING IN A UNIT KITCHEN" IN SPECIAL NURSING HOMES FOR THE AGED
}

- From the study of examination and analysis of living rooms and behavior tracking of cooking staffs -

$$
\text { 赤澤芳子*, 三浦＼cjkstart研** }
$$

\section{Yoshiko AKAZAWA and Ken MIURA}

This studies the effects and Issues of "Cooking in a Unit Kitchen" in Special Nursing Homes for the Aged from the Study of 14 hours examination and analysis in Living Rooms and Behavior Tracking of cooking staffs. We could get following conclusions.

1. Living Room environment in Special Nursing Homes is really important for the Aged from the data of 1) residents mean sojourn time in a Living Room was more than 7 hours and 2) mean mealtime was about 2 and half hours in 14 hours a day.

2. Watch over the Aged and communicate with the Aged would be prospected when cooking staffs work in a unit kitchen, because 2 cooking staffs were working more than 10 hours a day in front of the Aged.

3. Due to "Cooking in a Unit Kitchen", cooking sounds created a good family environment in a Special Nursing Home for the Aged.

\author{
Keywords: Cooking in a Unit Kitchen, Study of Behavior Tracking, Unit Kitchen, Meal \\ Good Family Environment, Special Nursing Homes for the Aged \\ ユニット調理, 行動観察調査, ユニットキッチン, 食事, 家庭的環境, 個室・ユニット型特養
}

\section{1. はじめに}

近年、認知症高齢者グループホームや宅老所など、住宅の規模に 近い小規模な施設が見直されている。施設内部の空間の使われ方も、 大広間での集団処遇から、家庭の居間に近い部屋で個別のケアを行 うことが良いと言われている。

全国に 6000 ヶ所、入居者 40 万人にのぼる特別養護老人ホーム (特養) は、2002 年以降「新型特養」と呼ばれる「個室・ユニット型」が標 準仕様になった。以後開設された施設の多くは、入居者全員が個室 を持ち、従来までの 4 床室に比べて格段にプライバシーを守りやす くなった。10 名前後の入居者でひとつのユニットを形成し、共有空 間としてリビングやキッチンを設け、建築空間的には以前より家庭 的な環境で過ごすことができるようになってきた。特養の居住空間 は飛躍的に改善されたといえる。

ところが、食事の提供についてはメインの厨房で大量調理が行われ、 温冷配膳車でユニットに運ばれてきた食事を一斉に食する方式の施 設が少なくない。建築的には各ユニットにダイニングキッチンが造 られ空間的には一般家庭の規模と設備に近づいたが、そこで実際に 日々の調理を行うことのできている「個室・ユニット型」特養は少 ないようである注1)。

\section{2. 研究の目的}

この研究では、2007 年 6 月現在全国に 881 ケ所存在し、今後も増
加が見込まれる「個室・ユニット型」特養における食事の提供方式が、 入居者および入居者の居住空間にどのような影響をもたらすのかを 調べる。具体的には、入居者が生活するリビングルームに隣接した キッチンで、日常的に調理を行っている先駆的な「個室・ユニット型」 特養を調查対象として、リビングの定点観察と調理職員の行動観察 調查を実施し、居住空間での調理がどのような効果と課題をもたら すのか、「ユニット調理」の効果を正確な実証データに基づき検証を 行うことを研究目的とする。

\section{3. 用語の定義}

\section{3-1 ユニット調理}

この論文では、一般的にユニット型施設で行われている基本的な食 事の提供方式と比較（表 1）して、「ユニット調理」を、入居者が生 活するユニットのリビングに隣接するキッチンにおいて、職員が日 常的に食事を作り、リビングに居合わせる入居者が調理の場面を感 じることが出来、入居者が自ら調理や片付けに参加することも可能 な調理方式と定義する。

例えば、炊飯やおやつ作りはユニットのキッチンで行うような場合、 行事のときのイベント食だけユニットで作るというような場合につ いては、この論文では「ユニット調理」とは定義しないこととした。 泥落としや下ごしらえをメインの影房で済ませ、その後の調理工程 をユニットキッチンで行う場合、たとえばメインの暦房で野菜を切 
り、ユニットキッチンで天ぷらにする場合は「ユニット調理」と定 義している。高齢者施設における食事の提供方式は施設ごとに異な り様々である。大切なことは、日常的に食事をユニットキッチンで 調理することとし、調理工程の多少は加味しないこととした。

\begin{tabular}{|c|c|c|}
\hline & $\begin{array}{c}\text { 一般なユニシト型施設における } \\
\text { 食事の提供 }\end{array}$ & $\begin{array}{c}\text { この論文で「ユニット調理」と } \\
\text { 定義する範囲 }\end{array}$ \\
\hline 為 & 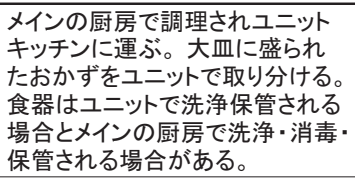 & 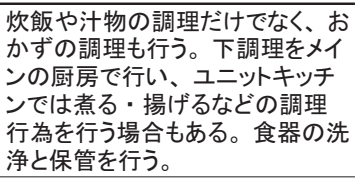 \\
\hline 調理対象 & 炊飯、汁物の温め、おやつ作り & 炊飯、汁物、主菜や副菜の調理 \\
\hline 頻 度 & 誕生会など行事のときだけ調理を & 日常的に調理を行う。 \\
\hline 担当者 & $\begin{array}{l}\text { メインの厨房では調理職員、ユ } \\
\text { 護職員。 }\end{array}$ & $\begin{array}{l}\text { ユニットキッチンで調理職員、介 } \\
\text { 護職員(勤務形態は常勤・パー } \\
\text { 卜委託を問わない)。入居者が } \\
\text { 参加する場合もある。 }\end{array}$ \\
\hline
\end{tabular}

\section{3-2 メインの㕌房}

施設内の給食業務をおこなう施設のことで、食材の納入から下処理、 調理のす心゙ての工程、多くの場合盛り付けまで行う。食事は、温冷 配膳車などを使用して食堂あるいはユニットの共有空間へと運ばれ、 下膳後は食器の洗浄、乾燥、（場合によっては消毒）保管まで行う。

入居者全員分の食事と、ときには職員食も一括して調理する。中央 の㕌房、センターキッチンと呼ばれることもある。

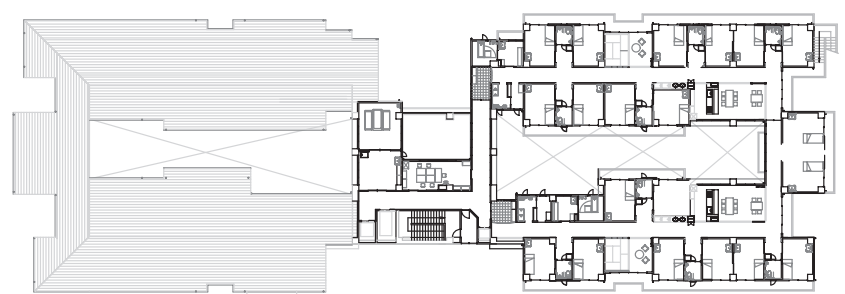

3 階平面図

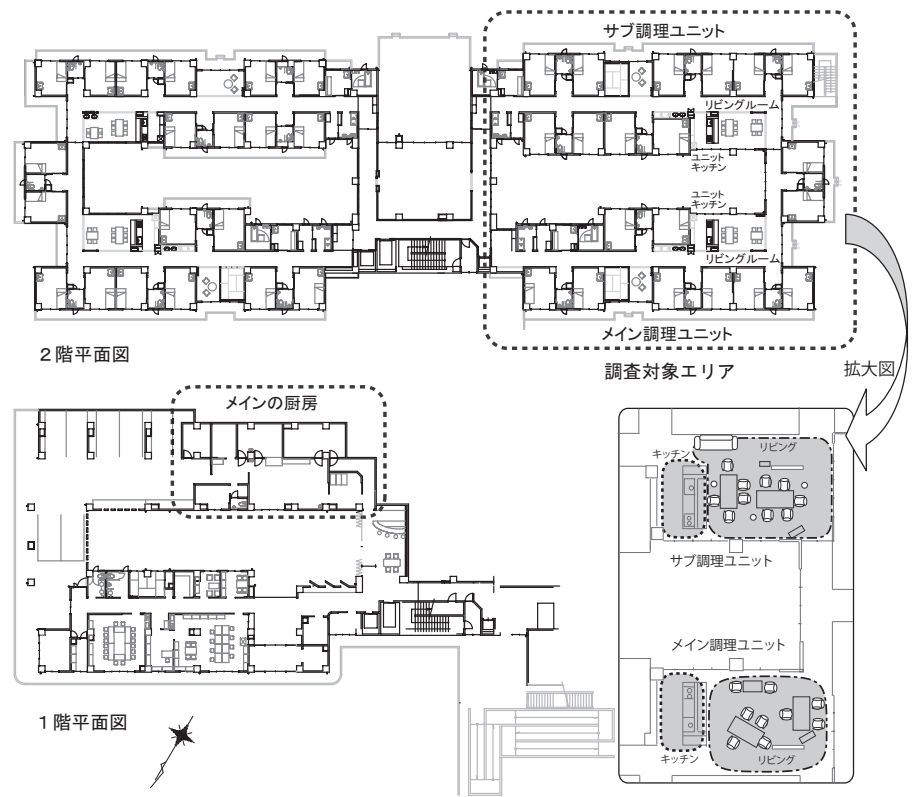

図 1 調查対象施設の平面図と調査リビングの拡大図

\section{4. 調査対象施設の概要}

調查対象とした「個室ユニット型」特養は、既存型の特養とケア ハウス、デイサービス等の在宅支援センターを含む京都府京丹後市 の高齢者総合福祉施設の敷地内に位置し、先駆的に「ユニット調理」 に取り組む特別養護老人ホーム T 園である。

\section{4-1 建物と設備の概要}

2005 年 8 月に竣工した鉄筋コンクリート造 3 階建て、延床面積は 3, $137 \mathrm{~m}^{2}$ の「個室・ユニット型」特養（図 1) である。定員は 60 名 (うち 10 名はショートスティ) で、10 名ずつ 6 ユニットを構成して いる。2 階に 4 ユニット、3 階に 2 ユニット配置されている。メイン の厨房は 1 階の東 (1 階平面図の左・破線囲み) に位置し、食材の納入・ 検品・下処理等が行われる。

向かい合う 2 ユニットがひとつのグループを作り、入居者（定員 20 名）とそこに配属されている職員の食事を一方のユニットで調理 する。片方のユニットキッチンにはスチームコンベクションと大容 量の電磁調理器が備えられ、もう片方のユニットのキッチンは一般 家庭用の調理台と調理設備が備えられている。以下、前者を「メイ ン調理ユニット」、後者を「サブ調理ユニット」と呼ぶ。

\section{4-2 職員体制}

この施設の職員配置は、1.86:1 (介護十看護 )、2.05:1 (介護 ) と なっている。ひとつのユニットに介護職員が $4 \sim 7$ 名配属されてい る。介護職員の人数がユニット毎に異なるのは、正規職員とパート タイマーなど勤務時間数に差があるためである。1 グループに 3 名 の調理職員を固定配置し、1 日に 2 名が出勤する。2 名の調理職員の 勤務時間は 8 時間と 5 時間で、日によって 2 名とも 8 時間の日、早 出 5 時間遅出 8 時間、早出 8 時間と遅出 5 時間という 3 種類の勤務 パターンがある。勤務パターンごとに業務分担、作業工程が決められ、 おおむね早出が朝食と昼食を、遅出が夕食を担当する。

4-3＼cjkstart調査対象ユニットの選定と職員の勤務シフト

調查対象ユニットは、 6 ユニットのうちショートステイを含む 2 ユ ニットを除き、かつ入居者の ADL を考慮して調査可能な 2 ユニット の選定を施設長に依頼し、2 階の西側（図1中央右・平面図に破線囲み）

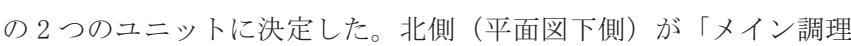
ユニット」、南側（平面図上側）が「サブ調理ユニット」である。こ の論文でリビングと呼ぶエリアおよびキッチンと呼ぶエリアを拡大 図に示した。ここは 3 層の建物の 2 階になるが、傾斜地に位置して いるため両ユニットとも段差なしに直接外部に出ることができる。

調査日の介護職員および調理職員の勤務シフトを（図 2) に示す。 調理職員 2 名の勤務時間は 6:00-15:00 と、11:00-20:00 であった。 介護職員はユニット毎に配属されているが、実際には両ユニットの 勤務者が協力してグループの入居者のケアにあたっていた。

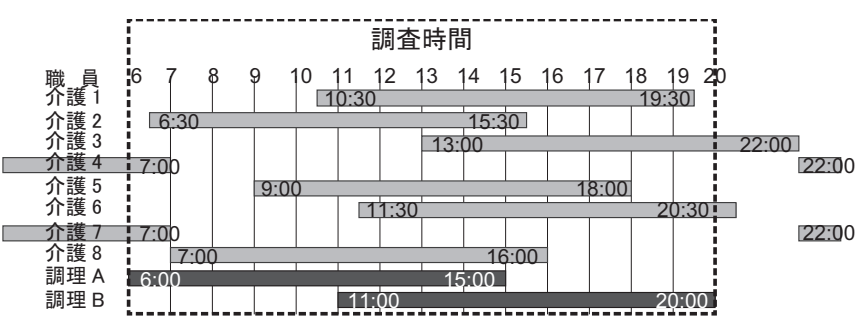

図 2 調査日の職員勤務シフト 
4-4＼cjkstart調査対象ユニットの入居者の属性と自立度（表 2）

調查対象ユニットの入居者は、調査日時点で「メイン調理ユニット」 (通番 1～9）９名と「サブ調理ユニット」(通番 10～19) 10 名である。 合計男性 3 名と女性 16 名、年齢は 2007 年 1 月 1 日現在 69 歳から 100 歳まで、要介護度は、 1 が 1 名、 2 が 3 名、 3 が 5 名、 4 が 6 名、 5 が 4 名であり、障害高齢者の日常生活自立度および認知症高齢者 の日常生活自立度は（表 2）に記載のとおりである。

表 2 調查対象ユニットの入居者の属性と自立度

\begin{tabular}{|c|c|c|c|c|c|c|c|c|}
\hline 通 & $\begin{array}{l}\text { 入 } \\
\text { 居 } \\
\text { 名 } \\
\text { 名 }\end{array}$ & 別 & 年 & $\begin{array}{l}\text { 年齢 } \\
2007 \\
1.1 \\
\text { 現在 }\end{array}$ & $\begin{array}{l}\text { 入 } \\
\text { 居 } \\
\text { 年 } \\
\text { 月 }\end{array}$ & 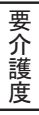 & $\begin{array}{c}\text { 障害 } \\
\text { 高齢者の } \\
\text { 日常生活 } \\
\text { 自立度 }\end{array}$ & $\begin{array}{c}\text { 認知症 } \\
\text { 高齢者の } \\
\text { 日常生活 } \\
\text { 自立度 }\end{array}$ \\
\hline 1 & M.A & 女 & 1923 & 84 & 2005.10 & 5 & C1 & IV \\
\hline 2 & S.N & 女 & 1927 & 80 & 2005.09 & 2 & B1 & II $\mathrm{b}$ \\
\hline 3 & S.K & 女 & 1926 & 81 & 2005.08 & 1 & B1 & II a \\
\hline 4 & I.S & 女 & 1918 & 88 & 2005.12 & 5 & $\mathrm{C} 1$ & II $\mathrm{a}$ \\
\hline 5 & Y.M & 女 & 1923 & 83 & 2005.08 & 3 & B1 & II $\mathrm{a}$ \\
\hline 6 & Y.N & 女 & 1916 & 91 & 2005.08 & 4 & B2 & IV \\
\hline 7 & M.M & 女 & 1922 & 84 & 2005.10 & 2 & B2 & III $b$ \\
\hline 8 & G.I & 勇 & 1909 & 98 & 2005.08 & 4 & B2 & III $\mathrm{b}$ \\
\hline 9 & S.O & 男 & 1938 & 69 & 2005.08 & 4 & $\mathrm{~A} 1$ & III $\tilde{b}$ \\
\hline 10 & H.I & 女 & 1907 & 100 & 2005.08 & 4 & A2 & III $b$ \\
\hline 11 & M.I & $\widehat{\text { 女 }}$ & 1925 & 81 & 2005.08 & 3 & J2 & III $\mathrm{a}$ \\
\hline 12 & T.O & 女 & 1919 & 88 & 2005.10 & 4 & $\mathrm{~B} 2$ & III $b$ \\
\hline 13 & T.O & 女 & 1911 & 96 & 2005.08 & 3 & A2 & III $\mathrm{b}$ \\
\hline 14 & M.K & 女 & 1912 & 94 & 2005.10 & 3 & A2 & III $a$ \\
\hline 15 & S.K & 男 & 1927 & 80 & 2005.08 & 2 & $\mathrm{~J} 2$ & III $a$ \\
\hline 16 & S.M & 女 & 1916 & 91 & 2005.10 & 3 & J2 & III $a$ \\
\hline 17 & R.M & 女 & 1917 & 90 & 2005.09 & 5 & B2 & $\mathrm{IV}$ \\
\hline 18 & T.Y & 女 & 1916 & 91 & 2007.09 & 5 & A2 & IV \\
\hline 19 & K.W & 女 & 1924 & 83 & 2005.09 & 4 & B2 & IV \\
\hline
\end{tabular}

\section{5. 調査の概要}

調查日時は、2007 年 8 月 8 日 (水)、午前 $6: 00$ から午後 8:00まで 連続 14 時間、調查対象ユニットのリビングに設置したビデオカメラ による撮影注 2) と、調理職員を対象とした行動観察調查を行った。

\begin{tabular}{|c|c|c|}
\hline \multicolumn{2}{|c|}{ 調理職員の行為 } & \multirow[t]{2}{*}{ 確認された音 } \\
\hline 調理行為 & 調理以外の行為 & \\
\hline 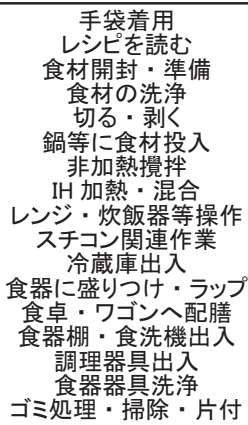 & $\begin{array}{c}\text { 食事 } \\
\text { 介助 } \\
\text { 会話·電話 } \\
\text { 入居者とだんらん } \\
\text { 打合·申し送り } \\
\text { 記録・検食採取・手洗 } \\
\text { 移動 } \\
\text { 休覟時間 }\end{array}$ & 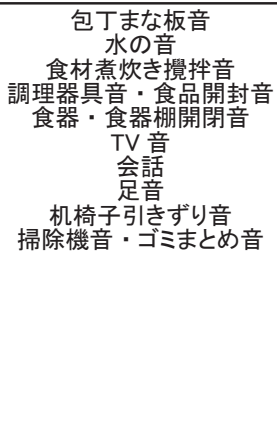 \\
\hline
\end{tabular}

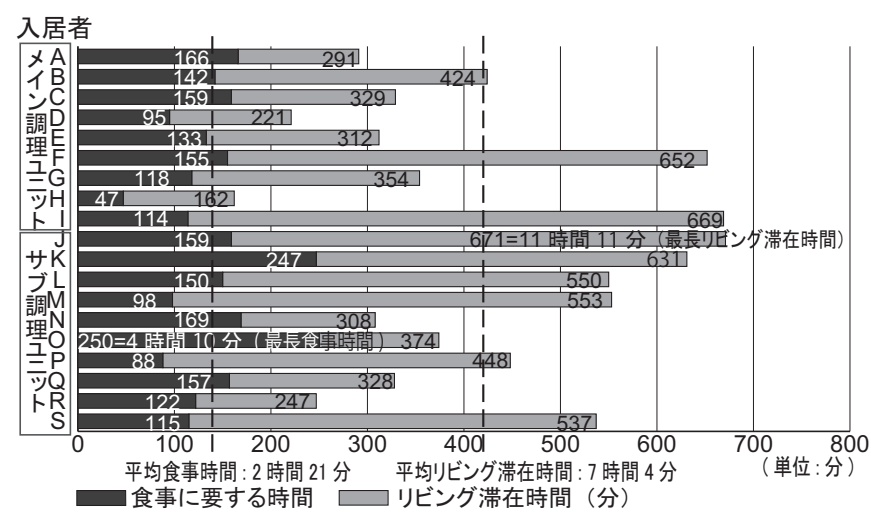

図 3 入居者のリビング滞在時間と食事に要する時間
ビデオテープから抽出したデータ（表 3）および、行動観察調査の 調查項目（表 4）を記す。

表 4 行動観察調查の調查項目

\begin{tabular}{|c|c|}
\hline 居場所 & $\begin{array}{l}\text { キッチン・リビング・ユニット間の廊下・ユニット・屋外・メインの厨房· } \\
\text { その他 }\end{array}$ \\
\hline & 調理関連行為・調理以外の行為 \\
\hline 会話相手 & 入居者・職員・その他 \\
\hline 会話内容 & 調理関連・介護関連・その他 \\
\hline 移動経路 & $\begin{array}{l}\text { ユニット内詳細・施設内・メインの線を記入 } \\
\end{array}$ \\
\hline
\end{tabular}

\section{6. 調理職員による入居者の見守り}

6.1 入居者のリビング滞在状況と食事時間

入居者のリビング滞在時間と食事に要する時間（図 3）については、 19 名の入居者のリビング滞在時間は平均 7 時間 4 分 (424 分)、最 短 2 時間 42 分（162 分）から最長 11 時間 11 分（671 分）であった。 そのうち 3 度の食事を摂るのに要した時間は平均 2 時間 21 分（141 分)、最短 47 分から最長 4 時間 10 分（250 分）である。リビングで 過ごす平均時間は調査時間 14 時間の半分を超えることを考えると、 食事室としての重要性に加えて、リビングは過ごし方の質が問われ る非常に重要な空間であることが認識された。

\section{2 介護職員のリビング滞在状沉}

職員のリビング滞在時間（図 4）について調べると、介護職員の 両リビング滞在時間は、 8 時間勤務者で 3 時間 47 分（227 分）から 5 時間 17 分 (317 分)、勤務者全員を 8 時間勤務に換算すると平均 3 時間 32 分 $(44.2 \%)$ に留まった。食事介助の必要な入居者も含む入 居者全員の食事時間の平均が 2 時間 21 分であることや、 7 時間以上 リビングで過ごす入居者もいることを考えると、介護職員が長時間 リビングに滞在するのは困難な実態が確認された。

6.3 調理職員のユニットキッチン・リビング滞在状沉

一方、調理職員のユニットキッチン滞在時間（図 4）は「ユニット 調理」を行うために比較的長く、14 時間の調查時間の $72.3 \% 、 10$ 時 間 8 分 (608 分)、8 時間換算にすると 5 時間 48 分であった。このこ

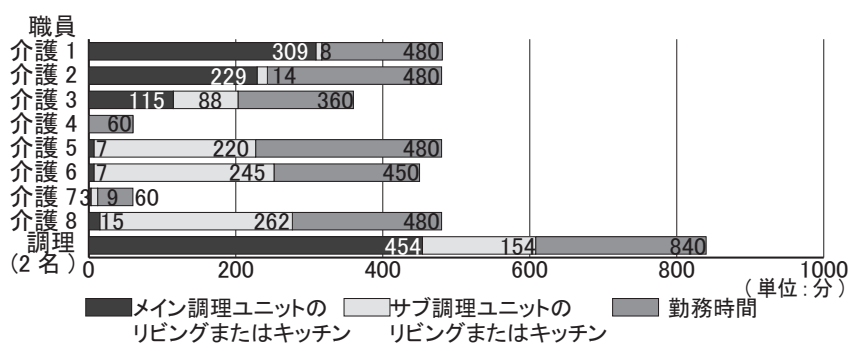

図 4 介護・調理職員の勤務時間と両リビング・キッチン滞在時間

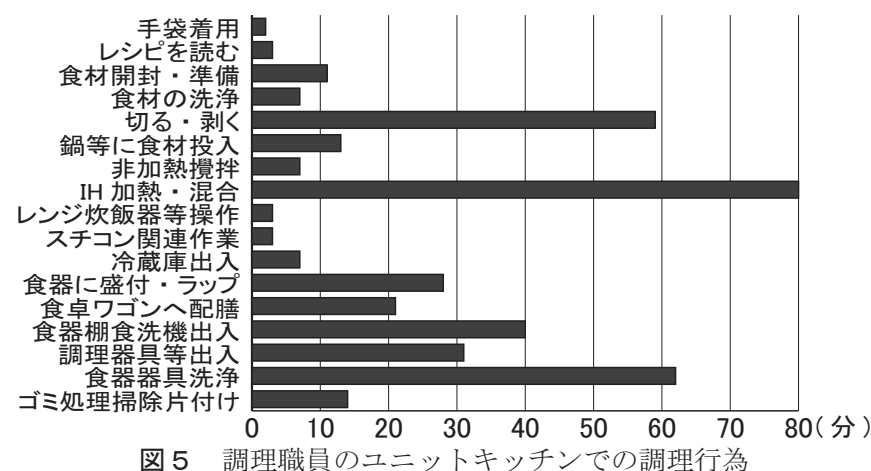


とから、介護職員が勤務時間の過半の時間をリビング不在にするの に対して、調理職員は勤務時間の 7 割以上を入居者に目の届く位置 に滞在していること、また 7 時間 34 分 $(54.0 \%)$ を「メイン調理ユニ ット」のキッチン、2 時間 34 分 (18.3\%) を「サブ調理ユニット」の キッチンで調理関連作業をしていることがわかった。

6.4 調理職員のユニットキッチンでの調理行為

調理職員のユニットキッチンでの調理行為（図 5) を調べると、行 為の種類は食事メニューに依存するので恒常的な比率であるかどう かは確認できていないが、調查日においては「IH加熱・混合」、「食 器器具洗浄」、「切る・剥く」行為の順に多く観察された。この調理 行為は、後で述べるユニットのリビングで確認される生活音に密接 に関係すると考えられる。

6.5 調理職員の目配り可能な時間帯について

(図 6) と、（図 7）は、それぞれ、「メイン調理ユニット」と「サブ 調理ユニット」のリビングに介護職員が不在時の調理職員による見 守り可能時間と滞在入居者数を、30 分毎の滞在入居者数（折れ線グ ラフ）と、介護職員のリビング不在時間（淡灰色棒グラフ）および

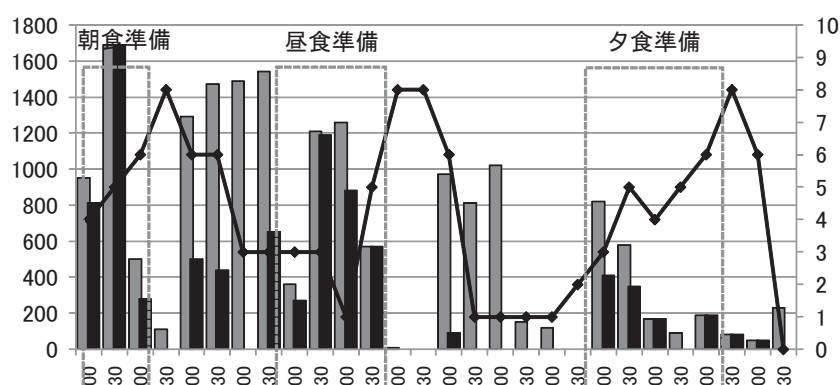

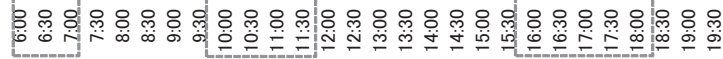

口介護職員不在時間 一調理職員見守り可能時間 30 分間の合計 (分) -滞在人数 (人)

図 6 介護職員不在時の調理職員の見守り可能時間 (メイン調理ユニットのリビング)

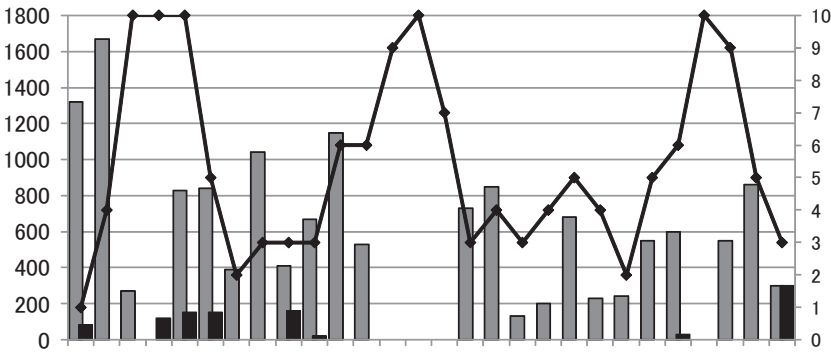

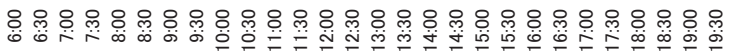

口介護職員不在時間

図 7 介護職員不在時の調理職員の見守り可能時間 （サブ調理ユニットのリビング）

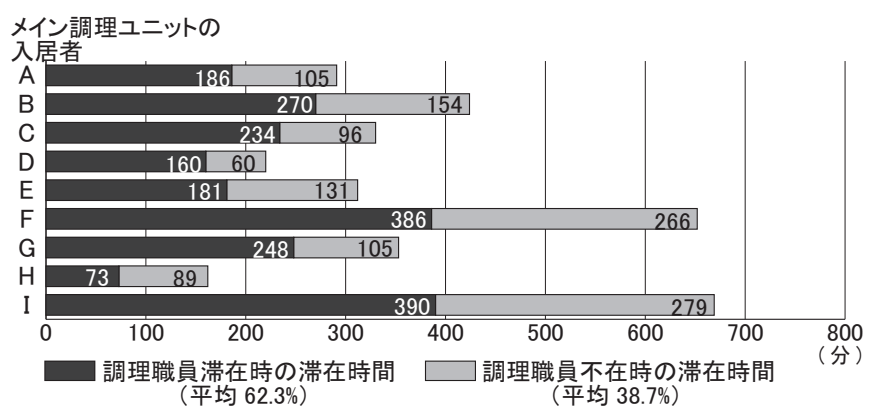

図 8 調理職員滞在・不在時の入居者の滞在時間 （メイン調理ユニットのリビング）
その時間帯に入居者とともに調理職員が滞在していた時間（濃灰色 棒グラフ）を表している。滞在者が増加するのは 3 度の食事の時で ある。この時間帯は配膳や食事介助などのため介護職員の滞在率は 高く、従って淡灰色の棒グラフは低くなり、介護職員は入居者に目 が行き届いていることがわかる。逆に、食事時間帯の前後の介護職 員は、入浴やトイレ介助、入居者の自室でのケア等のためリビング に滞在することは難しく、淡灰色の棒グラフは高くなっている。注 目す心゙きことは、「メイン調理ユニット」においては、調理職員が介 護職員の不在の時間帯にユニットキッチンで調理関連作業を行い、 そのことで結果的にリビングに滞在する入居者に目の届く位置に立 ち、入居者を見守る可能性が発生した。これは、メインの㕌房で調 理作業を行う場合には無かったことである。

（図 6,7）によると、介護職員のリビング不在時間は、特に午前中 に多く発生していることから、介護職員数の少ない午前の時間帯に ユニットキッチンに調理職員が滞在することによる見守り効果が期 待できる。また、 1 ユニットの介護職員数が 1 名増える午後には、(図 6) の黒い棒グラフ（介護職員のリビング不在時間に調理職員が滞在 している時間帯）があまり見られないが、これは、介護職員数が 1 名増えたことにより、不在時間が大幅に減少した結果である。

調理職員は、下膳と後片付けの時間帯よりもむしろ調理時間帯（朝 食 $6: 00 \sim 7: 05$ 、昼食 $9: 40 \sim 11: 45$ 、夕食 $15: 40 \sim 18: 20 ）$ の方が 入居者とともにユニットキッチンに滞在する時間が長く、入居者へ の見守りの可能性が高いことが明らかになった。

6.6 調理職員の滞在・不在時の入居者の滞在時間

「メイン調理ユニット」のキッチンにおいて、調理職員滞在時と不 在時の入居者のリビング滞在時間（図 8）は、平均すると入居者の

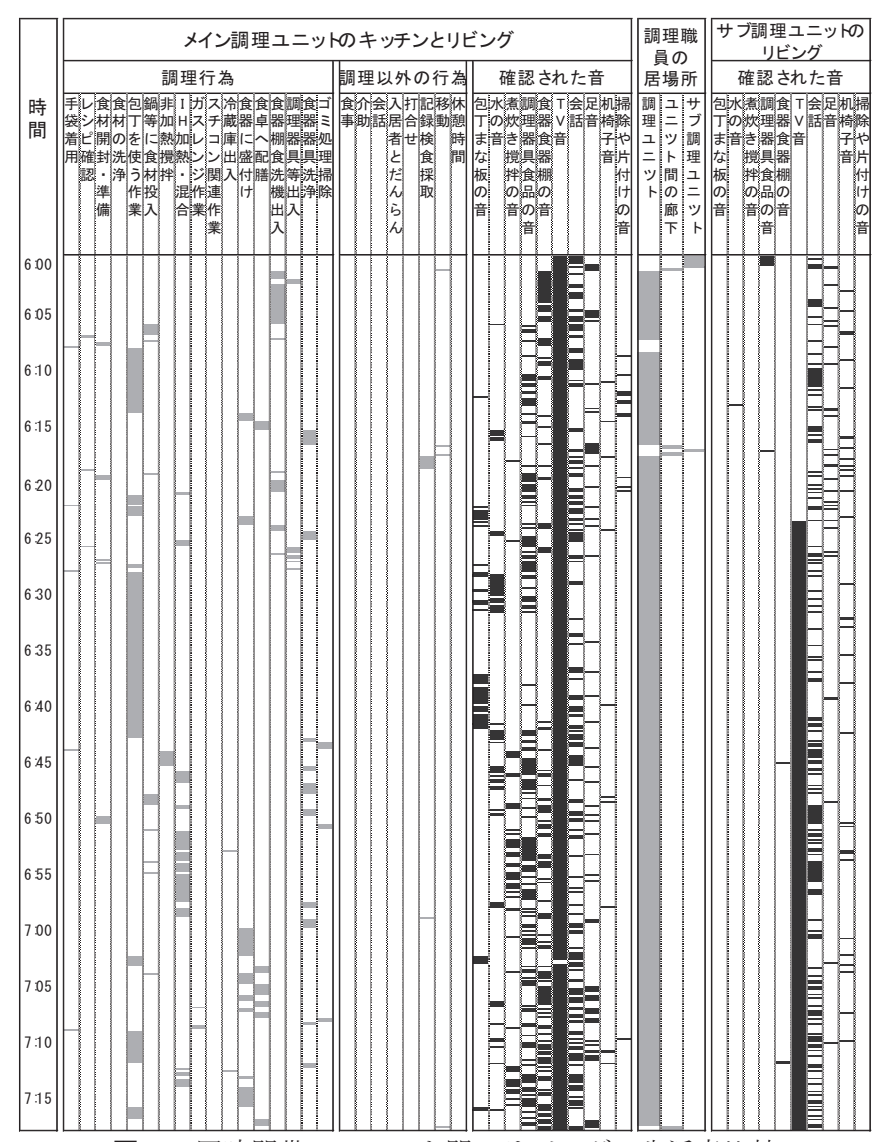

図 9 同時間帯のユニット間のリビングの生活音比較 
リビング滞在時間の $62.3 \%$ が調理職員の滞在時間帯であり、38.7\% が調理職員の不在時間帯である。このことは、調理職員が調理を行 う時間帯に入居者がリビングで過ごす傾向があることを示しており、 調理職員がユニットキッチンで作業している時間帯には入居者との コミュニケーションが生まれる可能性を示唆する。

6.7 調理職員の入居者見守りのまとめ

調理職員の入居者見守り可能時間（表 5）を調べると、調查時間 14 時間の中で、入居者が 1 人以上リビングに滞在した時間は、「メイン
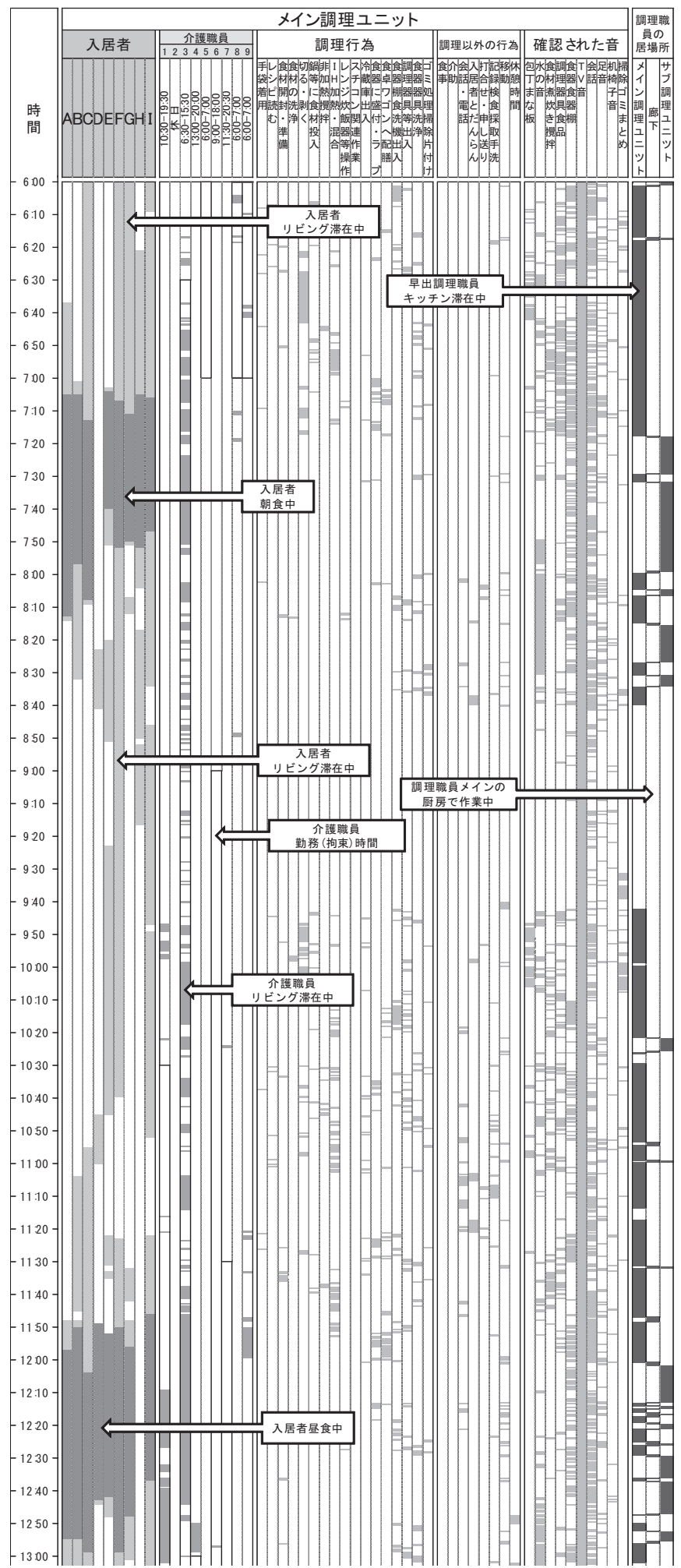

図 10
調理ユニット」のリビングで 13 時間 23 分、「サブ調理ユニット」の リビングで 14 時間であり、そのうち介護職員がリビングに滞在しな い時間は、それぞれ合計 4 時間 56 分と 4 時間 10 分であった。入居 者がリビングに滞在する時間の平均 $32 \%$ は介護職員の目が届いてい ない実態が明らかになった。

また、介護職員がリビングを離れ、再び戻るまでの時間を分析し たところ、「メイン調理ユニット」では平均 2 分 21 秒、「サブ調理ユ ニット」では 1 分 58 秒、最も長かったのは「サブ調理ユニット」の

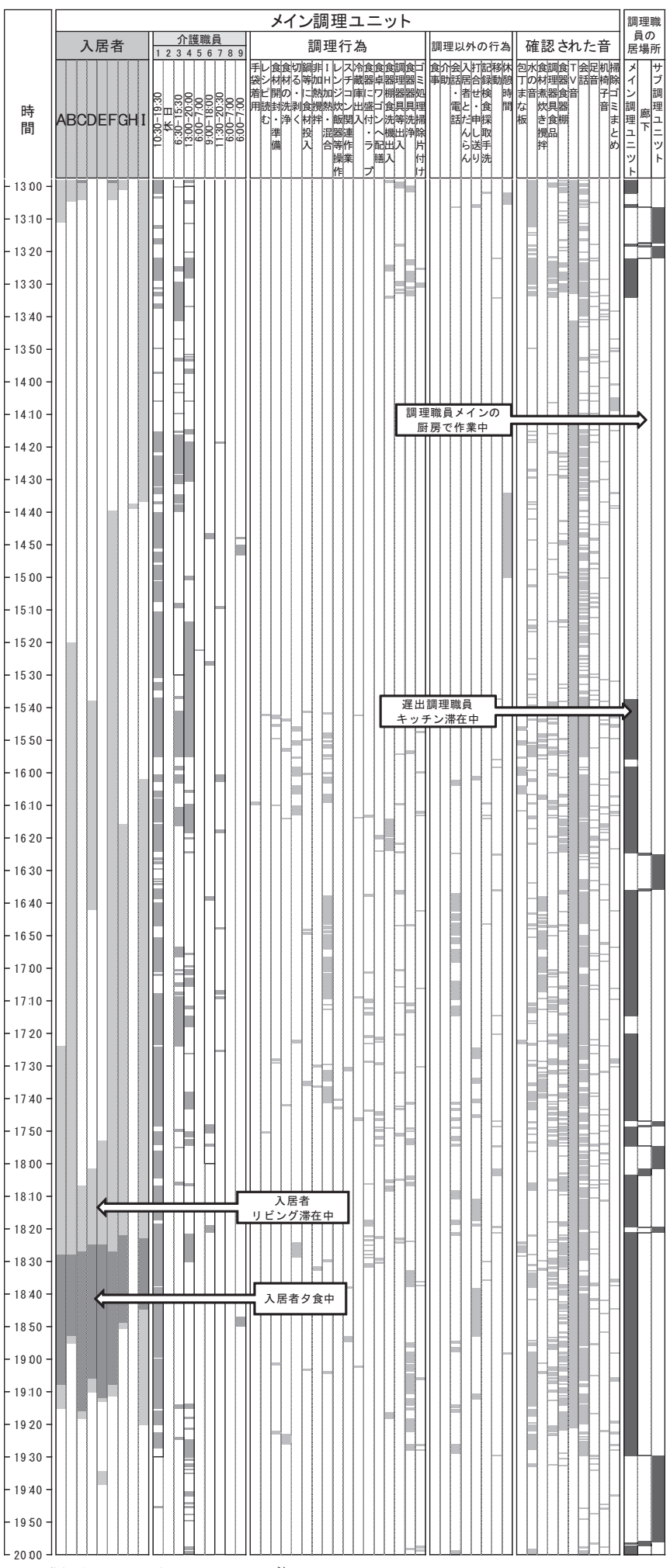

イイン調理ユニットのリビング) 
20 分 20 秒であった。一方、調理職員の「サブ調理ユニット」のキ ッチン滞在時間 2 時間 33 分のうち 16 分、「メイン調理ユニット」の キッチン滞在時間 7 時間 34 分のうち、介護職員のリビング不在時間 の $49.3 \%$ にあたる、2 時間 25 分もの時間、調理職員が入居者と一緒 にいたことから、「ユニット調理」を行っているリビングでは、介護 職員不在時間の約半分の時間、入居者に目の届く場所にいたことが わかった。このことからユニットに設備されたキッチンで調理する ことは、食事を作る業務以外の存在価值が確認できた。

表 5 調理職員の入居者見守り可能時間

\begin{tabular}{|c|c|c|}
\hline & $\begin{array}{c}\text { メイン調理ユニットの } \\
\text { キッチンだばング }\end{array}$ & $\begin{array}{c}\text { サブ調理ユニツトの } \\
\text { キッヂばだング }\end{array}$ \\
\hline 調理職員のリビング滞在時間 & 7 時間 34 分 & 2 時間 33 分 \\
\hline $\begin{array}{l}\text { ひとり以上の入居者がリビングに } \\
\text { 滞在している時間し }\end{array}$ & 13 時間 23 分 & 14 時間 \\
\hline $\begin{array}{l}\text { ひとり以上の入居者がリビングに } \\
\text { 滞在し介護職員か時間 }\end{array}$ & 4 時間 56 分 & 4 時間 10 分 \\
\hline 上記の回数 & 126 回 & 128 回 \\
\hline 1 回あたりの不在時間（平均） & 2 分 21 秒 & 1 分 58 秒 \\
\hline 1 回あたりの最長不在時間 & 18 分 20 秒 & 20 分 20 秒 \\
\hline $\begin{array}{l}\text { 介讗職員は不在であるが入居者 } \\
\text { と調理職員が滞在している時間 }\end{array}$ & 2 時間 25 分 & 16 分 \\
\hline 上記の回数 & 67 回 & 18 回 \\
\hline $\begin{array}{l}1 \text { 回あたりの見守り可能時間（平 } \\
\text { 均） }\end{array}$ & 2 分 11 秒 & 56 秒 \\
\hline 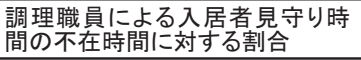 & $49.3 \%$ & $6.7 \%$ \\
\hline
\end{tabular}

\section{7. ユニットのリビングで観察される音}

7.1「メイン調理ユニット」と「サブ調理ユニット」のリビングで の同時間帯の生活音比較

午前 6 時から、7 時 18 分までの両ユニットのリビングの生活音比 較（図 9）を行った。左側が「メイン調理ユニット」のキッチンで の調理行為、調理以外の行為、リビングで確認された音で、右側が 調理を行っていない「サブ調理ユニット」のリビングで確認された 音を表した。調理職員はほとんどの時間「メイン調理ユニット」の キッチンで朝食準備をしており、リビングでは「包丁まな板音」や「食 材募炊き摚拌音」、「調理器具食品音」などが確認できる一方、「サブ 調理ユニット」のリビングでは、「TV音」や「会話」以外の音はあ まり発生していない。調理が行われているかどうかで観察される音 の種類と長さに大きな差があり、「ユニット調理」の実施によりさま ざまな生活音がリビングで聞き取れることが明らかになった。具体 的には「包丁まな板音」「水の音」「食材煮炊き擋拌音」「調理器具や 食器の音」などがリビングに滞在する入居者の耳に届き、調理の気 配を感じることができる。これはまさに一般家庭の居間の状況に似 ており、入居者の生活環境に良い影響をもたらすと考える。

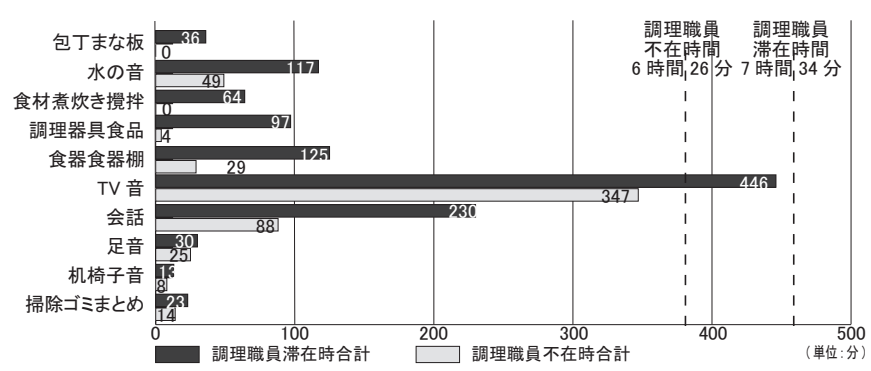

図 11 調理職員在室時・不在時に観察された音 (メイン調理ユニットのリビング)
なお、調理職員の居場所でグラフに表われていない時間帯は、主に メインの㕌房での作業およびそこへの移動時間、または休喤時間で ある。また、(図 2) より 11:00-15:00の時間帯に勤務する調理職員 は2 名であるので、(図 10) においては、13:40ごろまでは早出の、 15:40 以降は遅出の調理職員のデータである。

7. 2 「メイン調理ユニット」のリビングにおける 14 時間の生活音 の変化

「メイン調理ユニット」のリビングの 14 時間の生活音の変化（図 10）を表わすと、だれかがリビングに滞在している時に「会話」や「足 音」が発生するだけでなく、調理時間帯には「包丁まな板音」や「食 材募炊き擋挥音」、「食器・食器棚音」が発生し、下膳・後片付けの 時間帯には「水の音」が比較的長く続くことがわかった。このこと から、「ユニット調理」を行うと、作業の内容が変わるたびに発生す る音の種類や長さが変化することが明らかになった。また逆に、調 理時間や下膳・後片付け以外の時間にはリビングは比較的静寂に保 たれており、「ユニット調理」の実施がリビングにおける音環境に影 響している実態を時系列的に把握することができた。

\section{3 調理職員滞在時と不在時における音}

「メイン調理ユニット」のリビングで観察された音を、調理職員滞 在時と不在時に分けてまとめ（図 11）た。調理職員の滞在時間は合 計 7 時間 34 分、不在時間は合計 6 時間 26 分である。「包丁まな板の 音」、「食材煮炊き摚找音」は調理職員滞在時にしか発生せず、この ような調理関連作業をメインの麇房で行う場合は観察されない音で ある。調理職員不在時の「水の音」は入居者が食器を洗浄している ときの音で、調理職員がそばにいなくても入居者用の流し台を使用 して食器を洗浄していることが実証された。「会話」についても、調 理職員滞在時 (230 分) の方が不在時 (88 分) の 2.6 倍も観察注 3 ) さ れたことから、ユニットで調理作業を行うことは、調理職員と入居 者とのコミュニケーションに寄与寸ることを裏付けたといえる。

\section{8. 結論}

14 時間に渡る二つのユニットのリビングの定点観察と調理職員の 行動観察調查を実施した結果、以下の知見が得られた。

\section{1 リビングの空間としての重要性}

入居者の食事時間が平均 2 時間 21 分、最長 4 時間 10 分にもなるだ けでなく、滞在時間が平均 7 時間 4 分、最長 11 時間を超えることか ら、リビングは、食事室としての重要性に加えて過ごし方の質が問 われる非常に重要な空間であることが認識された。

8.2 見守りとコミュニケーションの可能性

介護職員のリビング滞在状況は勤務時間の $44.2 \%$, 時間勤務に換 算すると食事時間帯を含んでも 3 時間 32 分に留まった。平均 7 時間 以上過ごす入居者と比較すると、介護職員は落ち着いてリビングに 滞在することの困難な実態が確認された。また、入居者がリビング に滞在する時間の平均 $32 \%$ は介護職員の目が届いていないこと、介 護職員がリビングを離れ再び戻るまでの時間は平均 2 分 21 秒、最長 20 分 20 秒にものぼることが明らかになった。一方、ユニットキッ チンで調理する調理職員の滞在時間は、 2 名合計で 10 時間 8 分、 8 時間勤務に換算すると 5 時間 48 分にのぼる。特に、「サブ調理ユニ ット」の 3 倍の時間滞在する「メイン調理ユニット」のキッチンに おいては、介護職員不在時間の実に半分の時間を入居者に目の届く 
場所で過ごしている事実が確認でき、「ユニット調理」を行うことに より、入居者への見守りの可能性を高くすることが明らかになった。 また、入居者のリビング滞在時間の $62.3 \%$ が調理職員滞在時間であ ることから、入居者と調理職員のコミュニケーションも期待でき、 食事を作る業務以外の存在価值が確認できた。

8.3 音環境からみた家庭に近い空間の創出

朝食時間帯のふたつのユニットの生活音を比較すると、調理関連の 生活音が「メイン調理ユニット」のリビングで確認できる一方で、「サ ブ調理ユニット」のリビングでは、「TV 音」や「会話」以外の音は あまり発生していない。このことから、「ユニット調理」の実施によ りさまざまな生活音が発生している状況を把握することができた。

また、「メイン調理ユニット」のリビングで 1 日（14 時間）に観察 される音のデータから、「ユニット調理」を行うことにより発生する 音は種類や長さが時間とともに変化し、逆に、調理関連作業が終了 してからは、リビングは比較的静寂に保たれていることが示され、 「ユニット調理」の実施が、リビングにおける音環境に影響している 実態が時系列的に把握できた。調理職員が調理関連作業をユニット キッチンで行うことにより調理関連の生活音が発生し、より家庭に 近い環境を目指寸施設にとって、「ユニット調理」は入居者のそばで 調理するために見守りの可能性が発生し、家庭的な音環境を提供し、 入居者とのコミュニケーションを期待できるということにおいて非 常に有効である。このことは、入居者にとって良質な居住環境を提 供するという視点からも注目されて良い結果である。

\section{4 施設側の検討事項}

なお、今回調査した T 園では、人員配置の制約から 2 つのユニット の入居者全員分の食事を「メイン調理ユニット」のキッチンで調理 し、もう一方の「サブ調理ユニット」では、主として炊飯や食器洗 浄・保管を行っていた。本研究から明らかになった効果を考えると、 調理するユニットキッチンを片方に固定せず、曜日や時間など工夫 して調理場所を交互にするなど、より多くの利用者の前で調理する 試みも必用になると考えられる。

\section{9. 今後の研究の課題}

今回の研究対象施設では、 2 ユニットで 1 人の調理職員を配置して いたが、より人件費を抑えるために 3 ユニットで 1 人という案も考 えられる。いずれにしても入居者の目の前での調理を行いやすいこ と、ユニット間の連携が取りやすい平面計画であること、小型のス チームコンベクションなど調理設備の検討を行うことなどが必須で ある。さらに研究を重対「ユニット調理」を実現しやすくするため の建築計画上の留意点をまとめたいと考える。

\section{謝辞}

本研究の調查には、調查対象特養の入居者や職員の方々のご協力を いただいた。また、本研究は、文部省科学研究費補助金「大規模施 設のユニット化・サテライト化に対応した調理システムとその厨房 計画」（課題番号 19760431、代表:三浦 研）による研究成果である。 ここに謝意を表す。

\section{参考文献}

1）海道真妃，外山 義：特別養護老人ホームの個室化小規模ユニット化が入 居者の生活展開とケアに与える影響に関する研究 一多人数居室型から全個 室型への建替え事例の追跡調査を通して一, 京都大学工学研究科修士論文, 2002

2）毛利志保, 井上由起子, 谷口 元：小規模生活単位型特別養護老人ホーム におけるケア体制を踏まえた空間特性に関する研究，日本建築学会計画系 論文集 N0.572，pp. 41-47，2003.10

3）松原茂樹，足立 啓，赤木 徹也，船橋 國男，隼田尚彦，鈴木 毅，木 多 道宏：会話状況からみる痴呆性高需者の交流の変容に関寸る考察 - 痴呆 性高齢者のグループリビングへの移行に関する研究-, 日本建築学会計画系 論文集 N0.545，pp. 137-142，2001.7

4）松原茂樹，足立 啓，植野 知津子，舟橋 國男，児玉 桂子：入居者に対 する介護職員の関わりに関する考察 - ユニットケア型高齢者福祉施設にお ける介護職員のケアのあり方に関する研究-, 日本建築学会計画系論文集 N0. 561, pp. $137-144,2002.11$

5）山口健太郎，山田雅之, 三浦 研, 高田光雄 : 介護単位の小規模化が個別 ケアに与える効果 - 既存特別養護老人ホームのユニット化に関する研究 (そ の 1）-，日本建築学会計画系論文集 N0.587, pp. 33-40, 2005. 1

6）足立 啓，安岡 真由，品川靖幸，林 悦子，全国悉皆アンケート調査に よる従来型特別養護老人ホームのユニットケア実施状況と効果，日本建築 学会計画系論文集 N0.623，pp. 31-37，2008.1

7）三浦 研，赤澤 芳子：特別養護老人ホームにおけるユニット調理の効果と 課題（その 1）－アンケート調査による食提供の実態把握を通して一，日 本建築学会大会学術講演梗概集（中国）2008 年， N0. 5184，pp. 393-394, 2008. 9

8）赤澤 芳子，三浦 研：特別養護老人ホームにおけるユニット調理の効果 と課題（その 2）－行動観察調查による食提供の実態把握を通して一，日 本建築学会大会学術講演梗概集（中国）2008 年，N0. 5185，pp. 395-396, 2008. 9

注

注 1)「ユニット調理」を行っている施設の割合

筆者が 2007 年 8 月に調査した「個室・ユニット型」特養 167 件では、主菜（お かず）をメインの厨房で調理している施設は $93.9 \%$ であるのに対し、ユニッ トキッチンで調理している施設は $3.0 \%$ であった。なおこの調査については、 別報にて報告する予定である。

注 2) ビデオカメラによる撮影

カメラはひとつのリビングに 2 ケ所、合計 4 台設置し、データ抽出は 2 台の カメラを同時に再生し 10 秒毎に記録した。音声データについても同じビデ オテープを利用している。

注 3）会話の測定方法 :

(図 10) で確認された音の「会話」部分の積算時間である。2台のビデオを 同時再生し、10 秒ごとの瞬間に会話が発生していたらそれを 10 秒とし、10 秒以内に終了している会話はカウントしていない。 